\title{
The Power of Information Networks. New Directions for Agenda Setting, red. Maxwell McCombs, Lei Guo
}

\author{
Routledge, New York 2016, 235 ss.
}

DOI: $10.19195 / 1643-0328.22 .15$

Teoria agenda setting (AS) zajmuje ważną pozycję w badaniach nad komunikowaniem. Pozwala ona bowiem opisywać wpływ, jaki wywierają przekazy informacyjne na kształtowanie świadomości i opinii publicznej. Sama teoria zaczęła kształtować się już w 1922 r., kiedy Walter Lippmann opublikował książkę Public Opinion, gdzie przedstawił media jako łącznik między wydarzeniami na świecie a obrazami w naszych głowach ${ }^{1}$. Podążając śladem Lipmmanna, w 1963 r. Bernard Cohen ukuł twierdzenie, że media pozostawiają odbiorcom drogowskaz mówiący nie tylko o tym, o czym myśleć, ale również w jaki sposób myśleć o określonych wydarzeniach natury politycznej lub społecznej ${ }^{2}$. Kolejnym etapem rozwoju teorii była systematyzacja i kategoryzacja oraz formalizacja pojęć związanych z ustanawianiem agendy medialnej, dokonana przez Donalda Shawa i Maxwella McCombsa w 1972 r. Autorzy przedstawili koncepcję opartą na założeniach, że agenda medialna i polityczna istotnie wpływają na formowanie opinii publicznej, kierunkując uwagę odbiorców na wybrane wydarzenia ${ }^{3}$.

The Power of Information Networks. New Directions for Agenda Setting jest prezentacją kolejnego etapu rozwoju teorii ustanawiania agendy, w której nacisk położony został na sieciowy charakter relacji komunikacyjnych zachodzących między agendą medialną, polityczną i publiczną. Autorzy prezentują zupełnie nową perspektywę badawczą, która oparta została o założenie, że media informacyjne mogą determinować to, w jaki sposób publiczność kojarzy i łączy różne elementy przekazów w celu wykreowania zintegrowanego obrazu przestrzeni publicznej. Obok dwóch poprzednich poziomów agendy wprowadzony został trzeci - oparty na tradycji badań socjopsychologicznych.

Pozycja ta jest pierwszą, w której zaprezentowane zostały podstawy teoretyczne, podejścia metodologiczne oraz międzynarodowe badania empiryczne poświęcone trzeciemu poziomowi AS. Niewątpliwym atutem pracy jest wykorzystanie metod związanych $\mathrm{z}$ analizą sieciową, Big Data oraz wizualizacją danych, a nawet analizy semantycznej, które wydają się być obecnie niezbędnymi w podejmowaniu bardziej złożonych i skomplikowanych analiz zjawisk społecznych, politycznych czy medialnych.

Książka została podzielona na trzy części, które kolejno wprowadzają czytelnika w problematykę trzeciego poziomu AS. Część pierwsza została poświęcona opisowi perspektywy badawczej oraz teoretycznym i metodologicznym podstawom teorii. W rozdziale pierwszym, autorstwa Lei Guo, wyjaśnione zostały podstawy teoretyczne, które umożliwiają czytelnikowi poznanie najważniejszych założeń sieciowości i sieciowego charakteru procesu komunikacji. W rozdziale drugim przedstawione zostały zasady sieciowej analizy semantycznej oraz konstrukcji i wizualizacji map myślowych. Autorka (L. Guo) oparła swoje rozważania na przykładach kampanii gubernatorskich i prezydenckich w Stanach Zjednoczonych. W rozdziale trzecim Craig E. Carroll analizuje relacje komunikacyjne, jakie mają szanse zaistnieć w procesie komunikowania, dywersyfikując je pod

1 W. Lippmann, Public Opinion, New York 1922.

2 B. Cohen, The Press of Foreign Policy, New York 1963.

3 M. McCombs, D. Shaw, The agenda-setting function of mass media, „The Public Opinion Quartely” 36, 1972, nr 2, s. 176-187. 
względem liczby elementów wchodzących w skład procesu komunikowania. Autor w bardzo dokładny sposób przedstawia poszczególne elementy analizy sieciowej w oparciu o wzajemne stosunki mediów i publiczności z uwzględnieniem transpozycji uwagi poświęcanej danemu przekazowi.

Kolejna, druga część książki poświęcona została empirycznym badaniom międzynarodowym, w których autorzy wykazują istotę trzeciego poziomu AS w konstruowaniu świadomości publicznej odbiorców. W rozdziale czwartym Chris J. Vargo i Lei Guo poświęcili swoją uwagę zagadnieniu Big Data, analizując możliwości związane z wykorzystaniem oprogramowania komputerowego oraz podejścia metodologicznego do sieciowego modelu AS. Piąty rozdział pracy testuje założenia sieciowego modelu AS pomiędzy mediami tradycyjnymi a społecznościami w serwisie Twitter, których celem jest dyskusja na tematy polityczne. Sharon Meraz rozważa naturę wpływu medialnego w perspektywie codziennych rozmów na platformie społecznościowej, która toczy się poza oficjalnym kręgiem informacji politycznych, w tym kampanijnych. W rozdziale szóstym Nirit Weiss-Blatt podejmuje problem bloggerów technologicznych oraz ich wpływu na przepływ informacji. Autorka przeprowadza analizę sieciową wybranych blogów oraz produktów, prezentując wizualizację intermedialnych powiązań między wybranymi kwestiami. Tym samym wskazuje na rolę, jaką pełnią profesjonalni i nieprofesjonalni bloggerzy w procesie rozpowszechniania informacji. Magdalena Saldana i Alberto Ardevol-Abreu w rozdziale siódmym prezentują rozważania dotyczące wybranych atrybutów kwestii w gazecie „New York Times”. Autorzy dzięki połączeniu metod analizy dyskursu i analizy sieciowej przedstawiają skojarzenia oraz opinię publiczną dotyczącą problemu narkomanii. W rozdziale ósmym Lea Hellmueller i Claudia Mellado przedstawiają problem wydajności pracy dziennikarskiej w perspektywie usieciowionej agendy medialnej. Autorki prezentują wpływ profesjonalizmu dziennikarskiego na konstruowanie agendy medialnej w Stanach Zjednoczonych i Chile, które równocześnie stanowią różne systemy polityczne o różnym stopniu otwartości. Jisu Kim i Young Min w rozdziale dziewiątym rzucają światło na problem skomplikowanych relacji pomiędzy cechami wydarzeń, które mogą ulegać zmianie w bardzo krótkim czasie zgodnie z powstawaniem lub opadaniem publicznej i medialnej uwagi poświęconej danemu zagadnieniu. Spiro Kiousis i Matt Ragas w rozdziale dziesiątym przedstawiają i analizują zagadnienie związane $\mathrm{z}$ implikacjami trzeciego poziomu AS w stosunku do konstruowania relacji publicznych i komunikacji strategicznej. W kolejnym rozdziale Michael Etter i Anne Vestergaard rozważają problem sieciowego budowania i ustanawiania agendy podczas kryzysów korporacyjnych. Autorzy analizują transfer ważności informacji z organizacji pozarządowych przez medialne, aż do świadomości publicznej w serwisie Facebook. Z kolei Laura Illia, Philemon Bantimaroudis i Katia Meggaiorin podejmują próbę ukazania transferu ważności informacji w kontekście trzeciego — sieciowego poziomu AS. Autorzy wskazują, w jaki sposób przedsiębiorstwa rejestrują określone dane w swoich komunikatach prasowych, które następnie trafiają do mediów i opinii publicznej.

Ostatnią częścią książki jest podsumowanie, w którym redaktorzy Lei Guo oraz Maxwell McCombs analizują dotychczasowe rozważania nad teorią agenda setting oraz wyznaczają nowe kierunki jej rozwoju. Autorzy katalogują rozważania współautorów, umieszczając je w odpowiednich miejscach wywodu.

The Power of Information Networks niewątpliwie jest bardzo ważną pozycją w perspektywie nauk politycznych i badań komunikologicznych. Wykorzystane i zaprezentowane w niej metody badawcze rzucają nowe światło na badania nad wpływem medialnym oraz relacjami pomiędzy poszczególnymi aktorami życia społecznego i politycznego. Na szczególną uwagę zasługuje fakt, że czytelnik stopniowo wprowadzany jest w coraz bardziej skomplikowane zagadnienia dotyczące teorii AS (s. 24-27). 
Oparcie rozważań o analizę sieciową pozwala ukazać skomplikowany charakter relacji komunikacyjnych, które zachodzą między poszczególnymi aktorami komunikacji społecznej i politycznej. Interesującą w tym aspekcie wydaje się być prezentacja Carrolla, w której autor wyróżnia poszczególne elementy komunikowania ze względu na liczbę aktorów biorących w niej udział oraz natężenie relacji między danym medium, przekazem a odbiorcą (s. 37-38). Co więcej, autor prezentuje atrybuty i cechy charakterystyczne dla sieci komunikacyjnej oraz wskazuje jednostki wpływu zewnętrznego, które mogą implikować kształt, dynamikę oraz rozmiar wzajemnych relacji (s. 48-49). Dzięki zastosowanym koncepcjom otrzymujemy dosyć kompletny obraz wpływu komunikacyjnego, który może pochodzić zarówno z działań podejmowanych przez jednostki będące częścią procesu komunikowania, jak i czynników etycznych i psychologicznych. Przedstawiona w książce perspektywa oraz zastosowanie metod ilościowych i jakościowych pozwalają wyodrębnić i zidentyfikować grupy mniej lub bardziej istotnych atrybutów oraz liderów opinii, którzy mogą wpływać na kierunek dyskursu politycznego.

W pracy pojawiła się również koncepcja odwróconej AS przedstawiona przez Weiss-Blatt. Autorka prezentuje cztery modele AS i przepływu dwuetapowego (uwzględniającego elementy, takie jak: media-lider opinii oraz lider opinii-publiczność), rozważając jego kierunek (s. 90). W dobie rozwoju mediów społecznościowych wspomniany kierunek zdaje się być zgoła odwrotny. Przedsiębiorstwa medialne straciły monopol na dystrybucję informacji, co wpłynęło na dynamikę i kierunek przepływu określonych przekazów oraz pojawienie się zjawiska dziennikarstwa obywatelskiego.

Warta podkreślenia jest również wizja horyzontalnych i diagonalnych efektów trzeciego poziomu AS. Obrazy w naszych głowach opierają się o mimowolnie konstruowane mapy kognitywne. Saldana i Ardevol-Abreu rozważają psychologiczne dystanse pomiędzy niektórymi atrybutami, które mogą powodować nadawanie wysokiej lub niskiej rangi poszczególnym kwestiom, często posiadającym w przestrzeni publicznej status ważnych (s. 106).

Zmieniająca się wciąż przestrzeń informacyjna wymaga również uwzględnienia roli samych dziennikarzy pełniących w procesie komunikowania określone role. Niezwykle interesujące jest zestawienie wskaźników i modeli ról dziennikarskich z rodzajami źródeł informacji w USA i Chile (s. 122-127). Wykonane przez Hellmueller i Mellado badania uwidoczniły różnice między dwoma krajami, jeśli chodzi o postrzeganie roli dziennikarza w dwóch różnych rzeczywistościach politycznych i medialnych oraz znaczenie poszczególnych źródeł informacji.

Dosyć widoczną wadą książki jest brak prezentacji bardziej pogłębionych mierników związanych z metodą analizy sieciowej. Wszyscy autorzy skupili się jedynie na wizualizacji i korelacyjności danych, a nie na ich sieciowej analizie. Wiele do życzenia pozostawia również jakość niektórych grafów przedstawionych w książce, które mogą okazać się nieczytelne dla czytelników (s. 30, 202). Niemniej ujęcie problemów natury politycznej i społecznej z perspektywy badań komunikologicznych wydaje się być trafnym posunięciem. Wykorzystanie metod ilościowych, jakościowych oraz hybrydowych pozwala na w miarę rzeczywiste odzwierciedlenie zjawisk dotyczących poszczególnych kwestii nagłaśnianych przez media. Przedstawione w książce koncepcje i analizy pomagają zrozumieć $\mathrm{w}$ dość przystępny sposób procesy zachodzące w przestrzeni politycznej, publicznej i medialnej. Z pewnością pozycja przeznaczona jest dla badaczy nauk społecznych specjalizujących się w komunikowaniu i marketingu politycznym oraz komunikowaniu społecznym. 